\title{
PERANAN KONSULTASI KONSELOR SEKOLAH
}

\author{
Tri Anjar \\ Universitas Muhammadiyah Metro \\ E-Mail: anjar_tri69@yahoo.co.id
}

\section{PENDAHULUAN}

Konsultasi sebagai satu komponen bimbingan adalah segala usaha memberikan asistensi kepada seluruh anggota staf pendidik dan pada orang tua siswa demi perkembangan siswa yang lebih baik (Winkel, 1997). Sedangkan konseling adalah usaha membantu merefleksi diri siswa melalui wawancara konseling individual maupun kelompok, terlebih lagi bila permasalahan yang dihadapi siswa belum terselesaikan secara tuntas.

Konsultasi dalam kamus bahasa Indonesia dapat diartikan sebagai "pertukaran pikiran untuk mendapatkan kesimpulan berupa nasehat atau saran yang sebaik-baiknya". Konsultan dinyatakan sebagai orang ahli yang memberikan petunjuk atau nasehat dalam suatu kegiatan. Konsultasi diartikan sebagai tukar pikiran untuk meminta pertimbangan dalam memutuskan sesuatu. Artinya lebih menekankan pada unsur nasehat yang diberikan oleh orang yang berkompeten dibidangnya.

Konsultasi menurut Lippit (dalam Prayitno, 1989) konsultasi adalah urutan kedua strategi intervensi yang mencakup hubungan diantara pembantu profesional, konsultan, klien, konsulte dan kebutuhan bantuan target system. Konsultan adalah sesorang dari luar lingkungan system operasi klien, (system didefinisikan sebagai individu, organisasi kelompok atau fungsi unit social lainya), berusaha membantu klien dan membuat target perubahan yang positif. Biasanya hubungan ini dalam waktu sementara dan melibatkan semua kelompok yang akan produktif bila didasarkan pada kesukarelaan.

Dengan demikian, dapat diambil pengertian konsultasi sekolah adalah bantuan yang diberikan seseorang yang ahli pada orang yang meminta bantuan untuk memecahkan masalah yang melibatkan orang tua, personil sekolah, dan guru demi perkembangan siswa yang lebih baik. Sedangkan konseling adalah urutan pertama interversensi,dimana klien dan konselor secara langsung terlibat dalam membuat perubahan dan tidak orang lain yang dilibatkan

\section{PERANAN KONSULTASI DALAM BK DI SEKOLAH.}

Konsultasi diakui sebagai bentuk pelayanan yang yang khas kerena para konselor sekolah menyadari bahwa pelayanan langsung kepada siswa dalam kondisi tertentu tidak sepenuhnya membawa 
hasil seperti yang diharapkan. Konselor sering kali memiliki keinginan untuk bertindak sebagai konsultan bagi guru;guru untuk menciptakan lingkungan belajar yang positif bagi siswa, namun kebanyakan konselor tidak memberikan layanan konsultasi yang sistematis dan berkesinambungan, biasanya dalam bekerja dengan siswa secara peroraganan (Lombana, 1979; Mickelson \& Davis, 1977). Selain itu, program pendidikan konselor cenderung mengabaikan fungsi ini dan hanya sedikit menerima informasi atau tidak adanya latihan dalam teori yang sama/praktik konsultasi. Konsultasi dengan guru-guru biasanya secara langsung diarahkan pada kemampuan anggota serta difokuskan pada kebutuhan siswa secara individual dalam kelompok kelas atau kelas konsultasi ini dalam remedial/dalam rangka krisis ketika pembelajaran/kesulitan penyesuasaian.

Seperti yang dilakukan pada sekolah Menengah King George, Virginia. Program konsultasi didasarkan pada pengembangan model bimbingan yang didesain untuk membantu guru-guru tahun pertama masuk kelas 6 , membuat penyesuaian yang sukses pada situasi yang baru.

Pada awal tahun diadakan lokakarya untuk membantu guru baru dalam mengembangkan memejemen kelas efektif dan membantu siswa mencapai perubahan positif pada sekolah menengah. Tujuan konsultasi lainnya adalah :

1. Membantu guru menciptakan suasana produktif untuk belajar.

2. Membantu guru membentuk dan memelihara jalur komunikasi yang positif dengan orang tua.

3. Bimbingan menambah pemahaman guru tentang peran konselor dan menganjurkan penggunaan layanan.

4. Membuat jaringan komunikasi yang profesional dan dukungan untuk mengembangkan interaksi antara sesama guru.

Perencanaan dibutuhkan untuk kesusksesan program konsultasi yang komprehensif. Ada lima langkah bermanfaat,yaitu :

1. Meyakinkan kepala sekolah bahwa program tersebut potensial. Konselor sering mengeluh mereka tidak mendapat dukungan dari administrator dan melibatkan mereka dalam perencanaan akan membantu menciptakan kerja sama.

2. Mengadakan need assessment/penilaian untuk menentukan jumlah pelajar dan topik program yang difokuskan sesuai dengan kebutuhan siswa. Staf sekolah membuat catatan bahwa peralihan dari SD kelas 6 ke Sekolah Menengah cukup sulit.

3. Ketegangan dan proses mental secara menyeluruh. Persyaratan akademik yang bertambah mengakibatkan gejolak dan tingkah laku yang distruktif.

4. Mengakui kemungkinan daya tahan guru dan mengembangkan strategi untuk mengatasinya. Guru memiliki keengganan untuk ikut serta atau mendiskusikan masalah mereka secara terbuka dengan koleganya.

5. Memilih guru yang berpengalaman sebagai coleader yang dapat memberikan umpan balik dan dukungan pada kemajuan lokakarya. 
6. Perencanaan format yang cukup fleksibel untuk menemukan kebutuhan para peserta didik. Sehingga hubungan antara para guru dengan siswa semakin baik. Seminar difokuskan pad orang tua.

Sebagai kesimpulan seminar yang diadakan tersebut adalah semua guru yang menjadi bagian program merasakan efeknya pada pekerjaan dalam kelas dan membantu dalam berkomunikasi dengan lainnya tentang kelompok dan siswa individual. Peserta juga melaporkan pemahaman mereka tentang peran seorang konselor meningkat dan melanjutkan berunding secara tetap dengannya. Selain itu, guruguru seringkali berkomunikasi dengan orang tua berkenaan dengan tingkah laku siswa dan kemajuan akademik serta berpartisipasi beberapa orang tua dalam konfrensi kasus dengan konselor.

Lokakarya memberikan guru awal kesempatan untuk berbagi perasaan tentang pengalaman dalam kelas, mendiskusikan masalah dan teknis praktis untuk menata tingkah laku dan komunikasi dengan orang tua. Program juga meningkatkan konselor untuk membuat hubungan yang positif dengan guru baru, serta mendorong komunikasi terbuka berkenaan dengan siswa individual dan kelompok kelas.

\section{PERANAN KONSELOR DALAM PENYELENGARAAN KONSULTASI}

Konselor sekolah berfungsi sebagai konsultan yang memainkan peranan penting dalam membuat perubahan yang positif dan memudahkan pertumbuhan dan perkembangan klien yang dilayani.

Munro (dalam Prayitno, 1987) menggambarkan peran konselor dalam suasana berkonsultasi. Keterampilan konseling diterapkan dengan gaya dan suasana yang berbeda dalam konsultasi, yaitu suasana yang merupakan "hubungan tatap muka antara klien dan konselor" melainkan dalam susana konselor menghadapi pengaduan dari seseorang yang menyangkut suatu kejadian. Konselor tidak semata mempraktikkan keterampilan berkomunikasi/wawancara konseling tapi juga meninjau berbagai fakta dan suasana yang terkait dalam kejadian yang kedudukan serta mamanfaatkan sumber-sumber yang tersedia untuk menjernihkan dan mengatasi permasalahan yang timbul.

Pertanyaan seperti akankah waktu konselor diberikan pada konseling individual, akankah konselor bertanggung bertanggung jawab untuk jadwal siswa? Haruskah yang menjadi konselor adalah guru yang sudah pensiun? Akankah konselor A bertangung jawab untuk kelas 10, konselor B untuk kelas 11, dan konselor $\mathrm{C}$ untuk kelas 12? Apakah keberadaan konselor benar-benar diharapkan untuk membuat hubungan personal dengan 200,300,500 siswa? Dapatkah konselor memeberikan sumber daya manusia bersama dengan jadwal, orientasi, penempaatan, bimbingan kelompok, konseling individual, konferensi kasus dan administrasi tes untuk 200 siswa?.

Jawaban pertanyaan tersebut merupakan beban, fungsi dan pertanggungjawaban konselor yang harus digambarkan dengan jelas dan dibagikan. Model bimbingan harus dirubah dan cara yang berbeda harus dirumuskan untuk membangkitkan sumber daya manusia konselor.

Asusmsi mencakup peran dan fungsi konselor yang selalu tetap tidak realistis tentang kebutuhan utama pelajar sekarang serta kebutuhan yang akan datang. Sulit untuk membuktikan kebenaran dalam 
kekacauan hidup anak-anak, perceraian orang tua, minuman beralkohol, narkoba, upaya bunuh diri, macam-macam pelanggaran tata tertib sekolah, dan faktor yang berhubungan dengan ekonomi kaitanya dengan kebutuhan hubungan perkembangan perencanaan pendidikan, pilihan karir, penempatan kerja, juga hubungan dengan teman sebaya.

Beberapa pernyataan yang relevan untuk konselor, adalah bimbingan yang terdapat dalam "Education in 80's" (Clark,1979) :

1. Sekolah sekarang tidak mempersiapkan anak-anak untuk bermasyarakat.

2. Sekolah dibutuhkan untuk mendidik anak mengatasi perubahan.

3. Pendidikan mempersiapkan orang untuk melakukan fungsi masyarakat yang baik

4. Taman kanak-kanak akan berhenti tiga atau empat hari perminggu.

5. Tekanan kompetensi termasuk pengaturan diri, adaptasi, orang tua, memilih, evaluasi, pembentukan, peniruan dan penciptaan

6. Hati-hati dan humanis membongkar institusi lama.

Kategori bimbingan yang dibutuhkan secara luas agar siswa berhasil. Konselor juga akan berharap mengajari siswa dalam membuat keputusan, merencanakan, memilih, menanggulangi dan bagaimana menilai. Untuk itu konselor memerlukan keterampilan yang menonjol dalam konseling dan konsultasi, memberikan pengembangan pengalaman staf dan belajar menggunakan bakat untuk membantu pekerjaannya.

Kebingungan terhadap persepsi keprofesionalan dalam fungsi dan peran konselor didokumentasikan dalam literatur bimbingan. Bruce (dalam Prayitno, 1988) menganalisa persepsi peran konselor dengan melibatkan konselor, siswa, orang tua dan pengelola $50 \%$ dari konselor dengan tidak menyetujui kode rekomendasi ASCA-ACES. Konselor dan siswa tidak menyetujui peran konselor dalam hal konseling perorangan, layanan penempatan dan testing individual. Guru mempertanyakan tentang penggunaan waktu.

Jurang pemisah yang penting artinya terjadi pada area membantu siswa dengan masalah perorangan, disiplin dan karir. Orang tua mengharapkan konselor untuk mencurahkan tambahan waktu dengan anak-anaknya untuk mendiskusikan rencana pekerjaan serta pertemuan kelompok untuk membicarakan tentang sikap.

Beberapa pendapat mengenai aktivitas konselor adalah : Pertama, konselor mencurahkan waktu untuk menginformasikan aspek hak memasuki tinggi, bantuan beasiswa, seleksi kursus, karir dan lainlain. Kedua, waktu utama dicurahkan untuk membantu siswa mengidentifikasi kemampuannya, prestasi dan ketertarikan. Ketiga, aktivitas konselor banyak melibatkan orang dewasa lain (guru, orang tua, pengelola dan staf layanan siswa).

Konseling individu dan kelompok adalah tanggung jawab utama konselor. Tetapi yang penting adalah kemauan untuk menerima konsep konselor sebagai ahli, dasarnya adalah:

1. Konselor harus haarus memilki bakat khusus, pelatihan ,dan keterampilan 
2. Gambaran pekerjaan mencerminkan batasan fungsi keterampilan dan bakat,

3. Muatan kasus konselor harusnya mirip dengan ahli lainnya dalam pendidikan

4. Profesional dan para professional lainnya harus mengambil pertimbangan tipe pertanggungjawaban persetujuan konselor.

Di beberapa Negara yang konselornya dalam kategori maju, konselor merupakan guru yang mengajar secara penuh, diberikan pelatihan dengan kursus paruh waktu serta seminar akhir pekan oleh konselor ahli (spesialis). Tugas dan tanggung jawab konselor ahli disajikan dalam table berikut :

Tabel 1. Fungsional Tanggung jawab untuk Konselor Ahli dan Guru Pembimbing pada Sekolah Tingkat Menengah atas: kelas 9-12: 1500 pelajar

\begin{tabular}{|l|l|}
\hline Konselor ahli & (Guru) Konselor \\
\hline Konseling & Perencanaan Pendidikan \\
lindividual/Perorangan & Aktivitas Pengucapan/artikulasi \\
Kelompok & Seleksi kursus \\
Konsultasi & Informasi sekunder \\
Guru & Perguruan tinggi/universitas \\
Administrator/Penyelenggara & Sekolah teknik \\
Orang tua & Magang \\
Staf layanan murid & Dunia kerja \\
Pendidikan orang tua & Informasi karir/perencanaan \\
Program orang tua & Aplikasi pekerjaan \\
Konferensi & Wawancara \\
Publikasi/Pengumuan Bimbingan & Layanan bersenjata \\
Koordinasi & Pribadi sosial \\
Tim layanan murid & Pemahaman diri \\
Sumber daya masyarakat & Hubungan teman sebaya \\
Penempatan pendidikan Istimewa & Sumber daya sekolah \\
Pengembangan Staf & Alih tangan pada konselor ahli \\
Konselor umum & Konsultasi padaAhli kurikulum \\
Administrator/penyelenggara & Mengunakan staf Administrasi \\
Anggota staf lainnya & Evaluasi \\
Evaluasi & Sasaran/tujuan instruksional \\
Kebutuhan penilaian & Testing kelompok \\
Tujuan/sasaran & Ringkasan laporan \\
Testing Individual/perorangan & \\
\hline
\end{tabular}




\begin{tabular}{|l|l|}
\hline Format/sumatif & \\
\hline Kasus kira-kira 100-125 & Kasus kira-kira 100-125 \\
Perkiraan & Perkiraan dibutuhkan GURU KONSELOR \\
& 15 \\
\hline
\end{tabular}

Segi lain yang membedakan peran antara Konselor Ahli dan (guru) konselor termasuk pengembangan pelaksanaan bimbingan serta pengalaman untuk orang dewasa (guru, orang tua dan administrator). Konsultasi dengan orang dewasa lain yang tepat dalam kehidupan siswa, koordinasi informasi/layanan untuk menemukan kebutuhan siswa (system referral/alih tangan, psikolog, terapi kemampuan berbicara, kesehatan/medis) serta mengorganisasikan evaluasi aktivitas yang menyinggung program bimbingan secara menyeluruh. Ada tuntutan yang unik dalam pekerjaan konselor dan memerlukan pelatihan istimewa. Untuk memastikan pelatihan dengan tepat yang telah diberikan sesuai dengan kompetensi minimum, dilakukan pendemonstrasian sebelum sertifikat kompetensi diberikan.

Konselor sekolah sering mengahadapi situsasi berkenaan dengan masalah siswa yang bingung, administrasor yang sibuk serta orang tua yang prihatin. Dari masalah mereka, sedikitnya ada dua kesamaan. Pertama, dalam semua permasalahan yang diajukan ,mereka mengharapkan konselor melakukan sesuatu. Kedua, dalam semua situasi dapat diatur dalam parameter strategi intervensi yang dikenal dengan konsultasi. Konsultasi merupakan strategi intervensi yang tepat dan efektif untuk konselor sekolah.

Sebagai strategi intervensi, konsultasi tersebut sering digunakan tetapi jarang dipahami dengan baik. Konselor memiliki posisi yang unik dalam organisasi sekolah karena sering ditugaskan sebagai konsultan bagi guru-guru, administrator, kelompok khusus yang tertarik. Misalnya perguruan tinggi $A$, siswa dan orang tuanya (Many, dalam Prayitno, 1989) mendukung posisi konsultasi sebagai strategi intervensi yang tepat dan bermanfaat untuk konselor sekolah. Karenanya konselor harus memilki pemahaman yang kuat tentang prinsip operasional umum konsultasi diaplikasikan dalam setting dan pemahaman pertimbangan spesial yang dipakai pada tipe spesifik perorangan atau kelompok.

Tujuan konsultasi adalah membuat perubahan positif dalam sistem klien. Perubahan yang dimaksud adalah proses yang dihindari yang terjadi dalam dua cara :

1. Dari tindakan dan kekuatan yang tidak terkontrol oleh system (pasif) dan,

2. Dari usaha system mengatur pemecahan masalah dan pencapaian tujuan (aktif).

Perubahan positif terjadi bila sistem dengan aktif mencari prubahan yang menghasilkan pertumbuhan atau dasaar eliminasi masalah. Tujuan konsultan bekerja dengan system adalah membantu mereka mencapai penghargaan yang penuh dari potensi sendiri untuk mulai belajar dari perubahan itu. (Fullmer \& Bernard, dalam Prayitno,1989).

Perubahan kadang sulit dilaksanakan karena dipandang sebagai sesuatu yang baru, berbeda atau bahkan dianggap ancaman. Konsultan dapat mengurangi perlawanan untuk perubahan yang dibuat 
segera di mana sistem klien (konsulti dan target sistem) merasakan perubahan pada diri mereka sendiri dipercaya sebagai gagasan sendiri, dibawah kontrol mereka bukan perencanaan orang lain. Hal ini merupakan jawaban kenapa dalam hubungan konsultasi dibangun dengan kesukarelaan dan sementara.

Hal berikut adalah merupakan prinsip untuk membuat perubahan posistif yang harus diingat oleh konselor sekolah :

1. Didukung oleh sebagian besar orang-orang yang sangat berpengaruh dalam target sistem.

2. Terlihat sebagai pengurangan dari pada menimbulkan pertambahan beban.

3. Keserasian dengan nilai pernyataan dan target sistem yang ideal.

4. Menawarkan tipe tujuan, solusi atau pengalaman yang menarik target sistem.

5. Target sistem bukan merupakan perasaan ancaman bagi keamanan dan kemandirian.

6. Didukung oleh keputusan konsensus.

7. Target sistem setuju dengan apa yang mendasari atau tujuan dan perasaan yang sangat penting.

8. Target sistem menerima pengalaman, dukungan dan kepercayaan, kepercayaan diri dalam hubungan satu dengan yang lain.

9. Target sistem terlibat dalam evaluasi kemajuan dan membantu mempertimbangkan serta meninjau kembali tujuan bila pengalaman menunjukkan penyesuaian diri diinginkan.

Prinsip tersebut digunakan untuk memudahkan perubahan positif yang dapat dipakai untuk konsultasi dengan beberapa sistem klien. Prinsip yang lebih penting adalah bidang operasi melepaskan konsultasi dari sistem yang terlibat dalam konsultasi untuk melaksanakan prinsip perubahan yang efektif.

\section{TUJUAN UMUM KONSULTASI}

Ada empat tujuan umum konsultasi yang dapat diarahkan konsultan selama konsultasi yang merupakan dasar pengembangan yang konsisten dengan deferensi konsultasi dan membangun perubahan positif untuk memilki pengaruh yang bermanfaat pada konsultasi dan target sistem, konsultan dapat berusaha :

1. Membuat perasaan aktif dari kesadaran diri bagi konsulti dan target sistem. Kesadaran diri termasuk membuat system lebih sadar dari pengaruh internal dan eksternal yang membawa perubahan.

2. Memudahkan apresiasi untuk belajara dan mengerti tentang sistem yang mungkin lebih baik dan mampu menerima informasi yang menambah kesiapan peningkatan kesadaran.

3. Mempengaruhi sistem dengan cara seperti itu membuat mereka terbuka untuk perpaduan informasi baru kepada struktur keyakinan mereka dan kemungkinan fungsi penyesuaian diri. 
4. Menanamkan perasaan kompetensi dan kepercayaan tentang sistem penyesuaian dengan sistem mereka sendiri merupakan kemampuan untuk mengatur perubahan positif di masa depan.

Hubungan konsultasi didasarkan pada kesamaan. Klien yang berbeda dan situasi mengindikasikan kebutuhan bagi konselor untuk mengakrapkan lebih dari satu model konsultasi dan urutan menghadapi kebutuhan spesifik klen pada waktu khusus. Dengan variasi kebutuhan dan harapan klien, konsultan yang efektif akan menyesuaikan dengan model yang sesuai.

\section{MODEL KONSULTASI}

Hubungan konsultasi dimasuki konsulti untuk alasan yang bervariasi, biasanya konsulti yang potensial berhadapan dengan situasi dimana mereka kehilangan perubahan. Konsultan menggunakan bantuan menjamin konsulti berkeinginan untuk berubah. Keakraban dengan model konsultasi yang komprehensif membantu konsultan mengorganisasikan upaya mereka dan pengembangan strategi intervensi yang tepat. Upaya konsultasi dikategorikan Korpius (1978) dalam 3 model :

1. Model memperoleh layanan (Purchase of-Service Mode)

Model konsultasi ini diterapkan bila konsulti mengikutsertakan konsultan dalam proses dimana konsultan memberikan layanan langsung kepada target dan konselti memikul sedikit tanggung jawab untuk memudahkan proses perubahan. Seringkali konsulti menceritakan perhatian khusus tentang target dan menayakan konsultan untuk " mengubah atau menentukan " target.

Pada model ini konsultan menanyakan untuk menggunakan keahlian khusus aatu pelatihan kesiapan target sistem kontak langsung, tanpa melibatkan konsulti pada beberapa derajad kepentingannya. Hubungan tree party working merupakan metode paling baik untuk menjamin keterlibatan dan komitmen dari anggota yang penting pada target sistem. Keterlibatan setiap orang membantu sistem dalam belajar metode adaptasi yang mungkin berguna sebagai antisipasi masalah di masa depan. Model mmemperoleh layanan sering diterapkan di sekolah dan hubungan orant tua-konsultan. Namun tidak dianjurkan sebagai bentuk terbaik untuk memudahkan perubahan positif yang abadi.

2. Model Mediasi (Mediation Mode)

Bila masalah meliputi miskomunikasi, kurang komunikasi atau perselisihaan antara sistem, model yang digunakan adalah mediasi untuk membantu perkembangan perubahan. Konsultan menganalisa masalah dan perspektif komunikasi dan kesiapan usaha konsulti atau kontak pribadi langsung, mencoba mengembangkan fasilitas jalur komunikasi dengan target sistem.

Konsultan menerima tanggung jawab untuk menganalisa masalah dengan bantuan konsulti dan orang lain yang terlibat dalam kelompok. Konsultan melaksanakan rencana 
tindakan dengan bantuan konsulti, dan konsulti berperan besar dalam model ini dibandingkan dengan model layanan, memperoleh hasil pengembangan komitmen dan memberikan pengertian tanggung jawab terbesar untuk keberhasilan.

3. Model Kerjasama (Collaboration Mode)

Model ini lebih banyak dicontohkan dari pada model lainnya untuk keempat tujuan utama konsultasi yang telah dikemukakan. Karakteristik model ini konsultan dan konsulti saling kerja sama untuk menetapkan masalah,tujuan,strategi intervensi serta batasan waktu untuk proses konsultasi. Konsulti sering menuntut pelaksanaan intervensi dengan dukungan konsultan. Usaha evaluasi membawa kebersamaan.Jadi konsultan memberikan keahlian khusus dan mempercai konsulti un tuk menyampaikan informasi yang akurat, komitmen tingkat tinggi dan fasilitas tingkat keterampilan penggiriman.

Satu kemungkinan yang dapat dilihat, bagaimana konsultasi dimulai dengan sebuah mode dapat diubah ke model lain sebagai psroses konsultasi yang berhasil. Konsultan harus menyadari kekuatan dan kelemahan pribadi, parameter peran, konsulti serta sistem, karakteristik, bila ditetapka model yang lebih tepat untuk konsultasi yang digunakan dalam satu situasi khusus.

\section{PROSES KONSULTASI}

Proses konsultasi dilakukan dalam beberapa langkah dan berurutan untuk memastikan tidak ada yang terlupa dan pengalaman konsultasi bermanfaat untuk semua yang terlibat. Proses konsultasi disajikan dalam tujuh langkah :

1. Diawali dengan kontak ( hubungan) dan persetujuan.

2. Menegaskan hubungan dan mengumpulakan data.

3. Diagnosis dan pengembangan tujuan/sasaran-sasaran

4. Membangkitkan dan seleksi strategi intervensi

5. Implementasi pertemuan dalam rangka membentuk tentang hal yang terjadi dalam konsultasi

6. Memberikan dukungan dan evaluasi terhadap usaha penanggulangan

7. Pengakhiran dan tindak lanjut

Proses konsultasi dimulai apabila konsultan diminta konsulti untuk membantu memecahkan masalah, yaitu :

Langkah (1) Konselor membuat penilaian awal permasalahan dan menetapkan, jika konselor memiliki kemampuan, hasrat, waktu dan kecakapan peran untuk terlibat dalam penaggulangan masalah. Konselor juga membuat evaluasi awal keampuan konsulti untuk memudahkan perubahan dan mencapai persetujuan awal mengenai peran yang diharapkan dan dasar hubungan konsultasi. Jika persoalan ini tidak memuaskan konselor, konsultasi tidak akan diteruskan dan alih tangan adalah alternative yang terbaik dan dapat diterima. 
Langkah (2) Konselor mengumpulkan data dari konsulti dengan memperhatikan masalah dasar dan parameter untuk ditanggulangi. Kemudian megumpulkan data dan informasi lain dari sumber-sumber yang relevan (guru, saudara kandung, orang tua, sahabat, dan lain-lain), untuk mengembangkan diagnosa ditetapkan masalah dan tujuan secara baik.

Dengan penetapan masalah yang jelas data yang dikumpulkan relevan, konsultan dan konsulti mengembangkan penetapan tujuan peilaku khusus.Tujuan digunakan untuk membantu menetukan perubahan hasrat khusus serta membuat keiteria evaluasi. Tujuan yang lengkap termasuk siapa yang akan mengerjakaan apa, kapan,dalam keadaan bagaimana, sebagai evaluasi apa kreterianya. Jadi, kreteria evaluasi mnentukan dan prosedur ditetapkan pada langkah ini.

Langkah (3) Konsultan dan konsulti menghasilkan daftar yang memungkinkan buntuk strategi intervensi,menaksir kegunaan relative tentang keterangan siapa akan melakukan intervensi dan memilih rencana yang akan dilaksanakan. Sebagai rencana konsulti dan konsultan saling membantu berdasarkan model serta rencana persetujuan. Evaluasi akan selalu menjadi proses bersama bila memungkinkan.

Garis pedoman untuk pengakhiran, perlengkapan selama langkah awal,lebih sering ditentukan oleh susunan waktu atau pencapaian hasil tujuan sebagai pendekatan akhir konsultan mempersiapkan konsulti untuk memindahkan pertanggung jawaban atau memlihara, mengubah konsulti jadi penurunan keterlibatan aktif konsultan. Konsultan harus menindaklanjuti kemajuan konsulti untuk evaluasi perubahan jangka panjang dan prestasi umum tujuan konsultasi.

\section{PERANAN KONSELOR SEKOLAH DALAM KONSULTASI DENGAN GURU, KEPALA SEKOLAH DAN ORANG TUA}

Konselor sekolah dan Guru sering mengalami kekuarangan dan kesulitan dalam komunikasi sehingga untuk kedua belah pihak terasa kurang memuaskan. Akar kesulitan tersebut tidak hanya terletak pada salah satu pihak tetapi ada pada kedua pihak menunjukkan kekuarangan dalam sikap dan tindakan. Bila sikap konselor sekolah merasa lebih tahu dari Guru, dia akan jarang dihubungi untuk berkonsultasi. Seringkali guru memandang konselor sekolah sebagai ancaman terhadap harga diri atau tukang cerita yang memanjakan siswa. Konselor sekolah sebagai konsultan sebaiknya menghindari sikap serba tahu dan berusaha menciptakan hubungan kerjasama dengan mengakui keahlian guru dalam bidang yang dikelolanya, mengajak guru memikirkan persoalan dan memandang permasalahan sebagai sesuatu yang dapat dipecahkan bersama.

Guru dapat mempersilahkan untuk mengemukakan seluruh perasaan mengenai apa yang berlangsung di kelas, harapan, atau kekecawaannya sebagai guru. KomunikAsi seperti itu dapat membuat guru lebih rela meninjau kembali sikapnya sendiri. Ada kemungkinan konselor sekolah mengetahui 
kesulitan yang timbul antara guru dan siswa, dan menarik kesimpulan bahwa kesalahan tidak seluruhnya ada pada siswa. Konselor dapat mengarahkan focus diskusi pada guru dan membantunya mengadakan refleksi diri. Pembicaraan konsultasi dapat berkembang menjadi wawancara konseling.

Konsultan dapat melayani guru dalam banyak hal dan banyak cara,misalnua menjelaskan latar belakang psikologis dari reaksi pihak guru, menyadarkan guru akan ciri-ciri kebudayaan remaja, menunjukkan tantangan yang dihadapi remaja berkaitan dengan keadaan sosial budaya, perencanaan tindakan perbaikan terhadap siswa tertentu, interpretasi data psikologis merencanakan inti pembicaraan dengan orang tua. Pada akhirnya guru akan memberikan informasi kepada konselor tentang hal-hal lain yang sulit diketahui dari sumber lain, misInya hasil belajar siswa, klik yang terbentuk di kelas atau cara siswa mengerjakan aneka tugas yang dibebankan .bahkan konselor menghubungi guru untuk membicarakan masalah siswa. Konselor menjadi konsulti, dan guru menjadi konsultan.

Bagi pimpinan sekolah .konselor sekolah merupakan nara sumber yang sangat berarti, karena konselor sekolah banyak mengetahui tentang populasi siswa, misalnya alam pikiran dan perasaan mereka sebagai remaja, latar belakang ekonomi siswa, suasana lingkungan keluarga, harapan dan kekecewaan, kesulitan dalam mengerjakan tugas belajar. Namun peranan konselor tidaklah hanya terbatas sebagai nara sumber. Dalam kasus tertentu menyangkut jalannya kehidupan sekolah untuk membicarakan masalah yang belum terselesaikan atau untuk memahas garis-garis besar kebijaksanaan yang sebaiknya diambil.

Hasil pembicaraan konsultasi antara konselor sekolah dengan pimpinan sekolah berdampak sangat luas karena setiap perubahan positif dalam lingkungan sekolah mempengaruhi siswa bahkan staf tenaga pendidikan lain. Masalah disiplin, ekstrakurikuler yang dibina di sekolah mengandung nilai pedagogis asal tidak berada diluar jangkauan kemampuan ekonomi serta tidak jauh berbeda dengan kegiatan non akademik disukai remaja. Konselor dapat menyumbangkan pikiran yang memudahkan pimpinan sekolah untuk mengambil keputusan.

Selain itu konselor sekolah dapat menghubungi pimpinan sekolah atas inisiatif sendiri, bila diketahui ada permasalahan yang menyangkut suasana sekolah. Konselor secara obyektif mengemukakan fakta yang diketahui dan menyatakan kerelaannya untuk ikut memikirkan penyelesaian seandainya pimpinan sekolah meminta.

Konselor sekolah memiliki kesempatan untuk membina hubungan dengan orang tua ,dalam kedudukannya sebagai konsultan. Konselor mengambil inisiatif memanggil orang tua ke sekolah atau orang tua yang minta sendiri bertemu dengan konselor. Hal yang dibicarakan menyangkut kemajuan anak dalam belajar, pilihan sekolah lanjutan, perilaku anak di sekolah, sikap dan perilaku anak di rumah,kemungkinan mendapat bantuan finansial, alih tangan ke ahli lain di luar lingkungan sekolah, hubungan orang tua dengan remaja yang kurang memuaskan, pergaulan anak denagan lingkungan di luar sekolah serta interpretasi hasil testing. Konselor dapat menjelaskan kepada orang tua arti perilaku 
anak di sekolah, tantangan yang dihadapi anak di sekolah, cara komunikasi yang baik dengan anak dalam lingkungan keluarga, kegemaran dan ciri-ciri khas remaja serta program sekolah.

Orang tua dapat memberikan informasi tentang perilaku anak di rumah, hubungan dengan saudara-saudaranya, kesulitan yang digadapi keluarga berdampak pada anak, harapan dan kekecewaan orang tua, pertumbuhan dan perkembangan anak. Hasil yang diharapkan dari pembicaraan orang tua dan konselor sekolah adalah pengetahuan pemahaman tentang keadaan siswa. Bagi orang tua, hasil ini akan membawa komunikasi yang baik dengan anak.

Konselor harus dapat menciptakan suasana kebebasan untuk mengungkapkan pikiran dan perasaan orang tua tanpa merasa terancam harga dirinya. Mula-mula orang tua mengambil sikap pasif dan menyerang. Konselor harus menunjukkan keterampilan melunakkan sikap orang tua tersebut sehingga tercipta suasana saling tukar pandangan demi kebaikan anak. Komunikasi efektif hanya dapat berlangsung bila konselor mampu menciptakan komunikasi antar pribadi yang memuaskan untuk kedua belah pihak. Konselor dan orang tua mengkin sepakat agar konselor bicara langsung dengan siswa yang bersangkutan.

\section{DAFTAR PUSTAKA}

Prayitno. (1988). Orientasi Bimbingan dan Konseling, Jakarta: P2LPTK

Prayitno. (1987). Profesionalisasi Konseling dan Pendidikan Konselor, Jakarta :P2LPTK

Winkel, W. S. (1997). Bimbingan dan Konseling di Institusi Pendidikan, Jakarta : Grasindo 